\title{
Methylene Blue and Crystal Violet Dyes Removal (As A Binary System) from Aqueous Solution Using Local Soil Clay: Kinetics Study and Equilibrium Isotherms
}

\author{
Ahmed I. Abd-Elhamid ${ }^{1}$, Gomaa F. El Fawal ${ }^{2 *}$, Magda A. Akl ${ }^{3}$ \\ ${ }^{1}$ Composite and Nanomaterials Department, Advanced Technology and New \\ Material Research Institute (ATNMRI). City of Scientific Research and Technological \\ Applications (SRTA-City), New Borg El-Arab City, 21934, Alexandria, Egypt. \\ ${ }^{2}$ Polymer Materials Research Department, Advanced Technology and New Material \\ Research Institute (ATNMRI). City of Scientific Research and Technological \\ Applications (SRTA-City), New Borg El-Arab City, 21934, Alexandria, Egypt. \\ ${ }^{3}$ Chemistry Department, Faculty of Science, Mansoura University, Mansoura, Egypt.
}

\begin{abstract}
I N THIS PAPER, local soil clay as a low cost and affordable adsorbent was employed for the successful removal of methylene blue (MB) and crystal violet (CV) dyes from an aqueous binary system. The effect of various experimental conditions like adsorbate concentrations, time, temperature, and $\mathrm{pH}$ has been investigated. To know the adsorption performance of the dye molecules upon soil clay, the kinetics of the adsorption data were analyzed using various models such as pseudo-first-order and pseudo-second-order. This kind of study shows that the maximum adsorption reached at $2 \mathrm{~min}$ and uses the pseudo- second-order kinetics. The adsorption Kinetics have been investigated in the $\mathrm{pH}$ range of 2, 3.7, 7, and 8.7 at $25^{\circ} \mathrm{C}$ and analyzed with two different models namely Langmuir and Freundlich. The interaction of dye molecules with soil clay has been investigated by SEM, EDS, FTIR, and XRD. Maximum removal of $\mathrm{MB}$ and $\mathrm{CV}$ up to 47.82 and $35.71 \mathrm{mg} \mathrm{g}^{-1}$, respectively was achieved by dye molecules adsorption onto soil clay. This effective removal method may provide a promising solution for eliminating of $\mathrm{CV}$ and $\mathrm{MB}$ dyes from wastewater.
\end{abstract}

Keywords: Soil, Methylene blue, Crystal violet, Binary system, Dye removal, Wastewater.

\section{Introduction}

Clean water is essential for a healthy life. A nontoxic environment and fresh water are society's serious priorities. Yet, widespread pollution of fresh water and the industrial waste penetrating the ecosystem is beginning an alarming state. The development of agriculture and water system frameworks lead to more interest in water resources and especially for the treated wastewater in water system frameworks [1]. The presence of different environmental pollutants in drinking water has additionally increased worldwide health worries. Contamination of water bodies is mainly referred to the presence of toxic chemicals, including organic compounds (like dyes), and heavy metals [2]. Therefore, several techniques have been applied to treat the organics in wastewater; such as adsorption [3], nanofiltration [4], ozonation [5], and electroflotation [6]. Adsorption was found to be a perfect technique for wastewater treatment in terms of economic cost, the simplicity of design, insensitivity of toxic substances, and ease of operation $[7,8]$.

Dyes are the greatest serious environmental problems which delivered into the environment from many industrial processes, such as cosmetics, textile, paper, food, printing, plastic, pharmaceutical, and leather [9]. Their presence in water bodies is unwanted as they are difficult to remove due to their tenacious and recalcitrant nature [10]. Dyes in water are undesirable even at very low concentrations - highly visibleand need to be removed before the wastewater discarded into the environment [11]. As a result, the photosynthetic phenomenon of aquatic life is greatly affected owing to the reduced light penetration [12]. However, dyes are fairly difficult to biodegrade and eliminate from dye

*Corresponding author email: ahm_ch_ibr@yahoo.com; gelfawal@gmail.com

DOI: 10.21608/EJCHEM.2018.4113.1360

C2019 National Information and Documentation Center (NIDOC) 
wastewater owing to their complex aromatic molecular structures and high solubility in water [13]. There are several dye wastewater treatment methods presented, including photo-degradation, coagulation, chemical oxidation, reverse osmosis, membrane filtration methods, biosorption, and ozonation [14-19]. However, these methods have higher operating costs or are unproductive in dye wastewater treatment. Adsorption has attracted the attention owing to its numerous advantages, for example, low cost and high efficiency related to other dye wastewater treatment methods. Several of adsorbents have been studied for dyes removal from aqueous solutions like, corncob and barley husk, cocoa pod husks, palm kernel shell, spent tea leaves, ginger waste, metal-organic frameworks (MOFs), activated carbon, peat, chitin, silica and graphene oxide [11, 20-28]. In this way, the application of soil as adsorbents of toxic dyes received significant consideration in the last time due to their low cost, available in a large amount, high surface area, and nontoxic [29].

Crystal violet (CV) and methylene blue (MB) have dangerous effects on living organisms on little periods of exposure. MB is used extensively as a colorant in the textile industry such as wool, silk, and cotton. It can cause many health problems like eye burns, cyanosis, and irritation of the skin [30]. CV (related to triphenylmethane group) is widely used as an animal drug in veterinary. Moreover, it is utilized as a biological dye to identify bloody fingerprints [31]. It is unsafe for humans and can cause cancer when consumed or inhaled [31].

Most of the reports in the literature study the adsorption of single adsorbate from the solution onto solids. Limited studies deal with binary or ternary blends adsorption on the solid surfaces. So the intention of this study has investigated the use of local soil to remove of $\mathrm{MB}$ and $\mathrm{CV}$ dyes from the binary system. In addition, we also thoroughly studied the kinetics of different aspects affecting the adsorption procedures such as dye concentration, soil dose, $\mathrm{pH}$, and temperature.

\section{Materials and Methods}

\section{Materials}

Methylene blue (MB) and Crystal violet (CV) are purchased from Sigma-Aldrich (Germany) and used as received. Soil samples were obtained from Shoubk Ekrash village, Sharkia, Egypt.

\section{Methods}

Preparations of s-soil

The soil samples were dispersed in the lab. Briefly, $250 \mathrm{~g}$ of the presource soil (pr-soil) are added in $2.5 \mathrm{~L}$ distilled water with stirring at 500 $\mathrm{rpm}$ for $2 \mathrm{~h}$ to reach a high dispersion degree for the soils. The shaking sieve with a pore size (1,2 $\mathrm{mm}, 45,63,125,250$, and $500 \mu \mathrm{m}$ ) was used to separate the suspension to its different size. The suspended particles are divided into two different layers as seen in scheme 1. After that, the solidafter removing excess water- was dried at $90{ }^{\circ} \mathrm{C}$ for $24 \mathrm{~h}$. The lower layer (s-soil) was separated and used for dye removal experiments.

\section{Samples characterization}

Fourier transform infrared spectroscopy (FTIR) (Shimadzu FTIR-8400 S, Japan) was used to record the IR spectra of the soil. For all spectra, thirty scans were collected with a $4 \mathrm{~cm}^{-1}$ resolution.

$\mathrm{X}$-ray diffraction analysis of soil was done using Shimadzu X-ray diffraction (7000, USA, $\mathrm{Cu}-\mathrm{K} \alpha$ radiation). The radiation wavelength was $1.5406 \AA$ Á. The data were collected in the form of $2 \theta$ versus intensity (a.u) chart.

The surface morphology of the soil was analyzed using a scanning electron microscope (SEM) (JEOL, model JSM-6460LV, Tokyo, Japan) operated at an acceleration voltage of $20 \mathrm{kV}$. For this purpose, the soil pieces were coated with gold by JFC-1100E sputter (JOEL Ltd., Tokyo, Japan). Finally, elemental analysis was done using EDX.

\section{Adsorption Process}

The dye adsorption (by s-soil) was studied by determining the color change of the binary dye system (MB \& CV) in the aqueous solution. The binary dye solution stock was prepared by using $0.2 \%$ of $\mathrm{MB}$ and $\mathrm{CV}(1: 1)$ in distilled water. Many experimental parameters were studied in a kinetic manner with stirring speed $500 \mathrm{rpm}$ and the volume of the dye solution used was $20 \mathrm{~mL}$ such as dye concentrations (100, $200,300,400$ and $500 \mathrm{ppm}$ ), amounts of s-soil $(25-100 \mathrm{mg})$, and $\mathrm{pH}(2,3.7,7,8.7)$ in addition to the temperature $\left(25,40,55\right.$, and $\left.70{ }^{\circ} \mathrm{C}\right)$. Finally, $0.5 \mathrm{~mL}$ of the suspension was removed and centrifuged. After that, of $0.1 \mathrm{~mL}$ of the centrifuged solution diluted with distilled water to $10 \mathrm{~mL}$ for further measurement. $\mathrm{MB}$ and $\mathrm{CV}$ concentration were measured at 662 and $590 \mathrm{~nm}$, respectively, using UV/Vis Spectrophotometer (Double beam) (T80+, PG Instruments Ltd., UK.) [32-34]. 
The dye removal efficiency ( $\mathrm{R} \%$ ) is defined by Eq.1:

$$
\mathrm{R} \%=\frac{\left(\mathrm{C}_{\mathrm{o}}-\mathrm{C}_{\mathrm{t}}\right)}{\mathrm{C}_{\mathrm{o}}} \times 100
$$

Where $\mathrm{C}_{t}$ is the concentration of dye at time $t$, and $\mathrm{C}_{\mathrm{o}}$ is the initial concentration.

\section{Experimental parameters}

Effect of dye concentration

The effect of dye concentration $(100,200$, 300,400 , and $500 \mathrm{ppm}$ ) on the removal percent (R \%) was studied. The adsorbent dose was $5 \mathrm{~g}$ $\mathrm{L}^{-1}$, the solution $\mathrm{pH}$ was 7 and the temperature was $25^{\circ} \mathrm{C}$.

\section{Effect of soil clay dosage}

The effect of soil dosage was done in the concentration range of $1.25-5.0 \mathrm{~g} \mathrm{~L}^{-1}$. The study was achieved at $\mathrm{pH} 7$, at $25^{\circ} \mathrm{C}$ for $10 \mathrm{~min}$, and the initial dye concentration was $300 \mathrm{ppm}$.

\section{Initial $\mathrm{pH}$ effect on the dye removal}

The effect of $\mathrm{pH}$ range $(2,3.7,7$, and 8.7$)$ on the $\mathrm{CV}$ and MB dye adsorption was studied. The study was achieved with an initial dye concentration of $300 \mathrm{ppm}$, at $25^{\circ} \mathrm{C}$ for $10 \mathrm{~min}$, and the adsorbent dose was $5 \mathrm{~g} \mathrm{~L}^{-1}$.

\section{Effect of the temperature on dye removal}

The temperature ranges effect $(25,40,55$, $70{ }^{\circ} \mathrm{C}$ ) on the adsorption of $\mathrm{CV}$ and $\mathrm{MB}$ dyes was studied. The study was done with initial dye concentration of $300 \mathrm{ppm}$, the adsorbent dose was $5 \mathrm{~g} \mathrm{~L}^{-1}$ and $\mathrm{pH}$ was 7 .

\section{Adsorption kinetics}

Two well-known kinetic models were investigated. Pseudo-first-order presented by Lagergren equation [35] Eq. 2.

$$
\log \left(\mathrm{q}_{\mathrm{e}}-\mathrm{q}_{\mathrm{t}}\right)=\log q_{e}+\frac{\mathrm{K}_{\mathrm{ads}} \mathrm{t}}{2.303}
$$

Where $\mathrm{q}_{\mathrm{e}}\left(\mathrm{mg} \mathrm{g}^{-1}\right)$ is the amount of sorption at equilibrium time, $\mathrm{q}_{\mathrm{t}}\left(\mathrm{mg} \mathrm{g}^{-1}\right)$ is the amount of sorption at time $t$, and $\mathrm{K}_{\mathrm{ads}}\left(\mathrm{min}^{-1}\right)$ is the rate constant of pseudo-first-order sorption. $Q_{e}$ and $q_{t}$ can be calculated by Eq. 3 and 4 .

$$
\mathrm{q}_{\mathrm{e}}=\frac{\left(\mathrm{C}_{\mathrm{o}}-\mathrm{C}_{\mathrm{e}}\right) \mathrm{V}}{1000 \mathrm{w}}
$$

Where $\mathrm{C}_{\mathrm{e}}$ is the dye concentration at equilibrium time $\left(\mathrm{mg} \mathrm{L}^{-1}\right), \mathrm{C}_{\mathrm{o}}$ is the initial concentration $(\mathrm{mg}$ $\left.\mathrm{L}^{-1}\right), \mathrm{V}$ is the volume of dye solution $(\mathrm{mL})$, and $\mathrm{W}$ is the mass of adsorbent $(\mathrm{g})$

$$
\mathrm{q}_{\mathrm{t}}=\frac{\left(\mathrm{C}_{\mathrm{o}}-\mathrm{C}_{\mathrm{t}}\right) \mathrm{V}}{1000 \mathrm{w}}
$$

Where $C_{t}$ is the dye concentration at different time $\left(\mathrm{mg} \mathrm{L}^{-1}\right)$

Pseudo-second-order expressed by Ho equation [36] the equation developed in a linear form as Eq. 5.

$$
\frac{\mathrm{t}}{q_{t}}=\frac{1}{K_{2} q_{e}^{2}}+\frac{t}{q_{e}}
$$

Where $\mathrm{K}_{\text {ads }}\left(\mathrm{g} \mathrm{mg}^{-1} \mathrm{~min}^{-1}\right)$ is the rate constant of pseudo-second-order reaction.

\section{Adsorption isotherm}

The adsorption isotherm model was used to clarify the interaction between the adsorbate and the adsorbent. The most famous models used for the description of it are Langmuir (Eq. 6) and Freundlich (Eq. 7).

$$
\begin{gathered}
\frac{\mathrm{C}_{e}}{\mathrm{q}_{e}}=\left(\frac{1}{\mathrm{bq}^{0}}\right)+\left(\frac{1}{\mathrm{q}^{0}}\right) \mathrm{C}_{\mathrm{e}} \\
\log \mathrm{q}_{e}=\log \mathrm{K}_{\mathrm{f}}+\frac{1}{\mathrm{n}} \log \mathrm{C}_{\mathrm{e}}
\end{gathered}
$$

Where $\mathrm{C}_{\mathrm{e}}$ is the equilibrium concentration (mg $\left.\mathrm{L}^{-1}\right), \mathrm{q}_{\mathrm{e}}$ is the amount adsorbed at equilibrium time $\left(\mathrm{mg} \mathrm{g}^{-1}\right)$, $\mathrm{q}^{\circ}$ is the maximum dye species uptake per unit mass of adsorbent $\left(\mathrm{mg} \mathrm{g}^{-1}\right)$, and $b$ is Langmuir constant $\left(\mathrm{L} \mathrm{mol}^{-1}\right) . \mathrm{K}_{\mathrm{f}}\left(\mathrm{mg} \mathrm{g}^{-1}\right)$ and " $\mathrm{n}$ " are Freundlich constants.

Whereas $R_{L}$ designates the shape of the isotherm and can be obtained from Eq. 8:

$$
R_{L}=\frac{1}{1+b C_{o}}
$$

Where the $R_{L}$ is the separation parameter $\left(R_{L}>1\right.$ unfavorable, $\mathrm{R}_{\mathrm{L}}=1$ linear, $0<\mathrm{R}_{\mathrm{L}}<1$ favorable, $\mathrm{R}_{\mathrm{L}}$ $=0$ irreversible)

\section{Results and Discussion}

\section{UV-Vis-spectrum}

Figure 1a exhibits the characteristic reflections of the $\mathrm{MB}, \mathrm{CV}$, and binary system dyes (MB\&CV) using UV-Vis-spectrum. In the individual system, $\mathrm{MB}$ and $\mathrm{CV}$ dyes show maximum peak absorption at 662 and $596 \mathrm{~nm}$, respectively. On the other hand, $\mathrm{MB} \& \mathrm{CV}$ dyes in binary system exhibit two maximum absorption peaks in the visible spectral region (662 and $596 \mathrm{~nm}$ ) and three other small peaks in the UV region (294, 248 and $208 \mathrm{~nm}$ ), which confirm the existence of both dyes in the solution. Those results agree with previous other work [32-34].

Upon the dilution of the dye solution, the intensity of the peaks decreases in both UV and Vis-regions as illustrated in Fig. 1b. This confirms that the dilution cause concentrations 


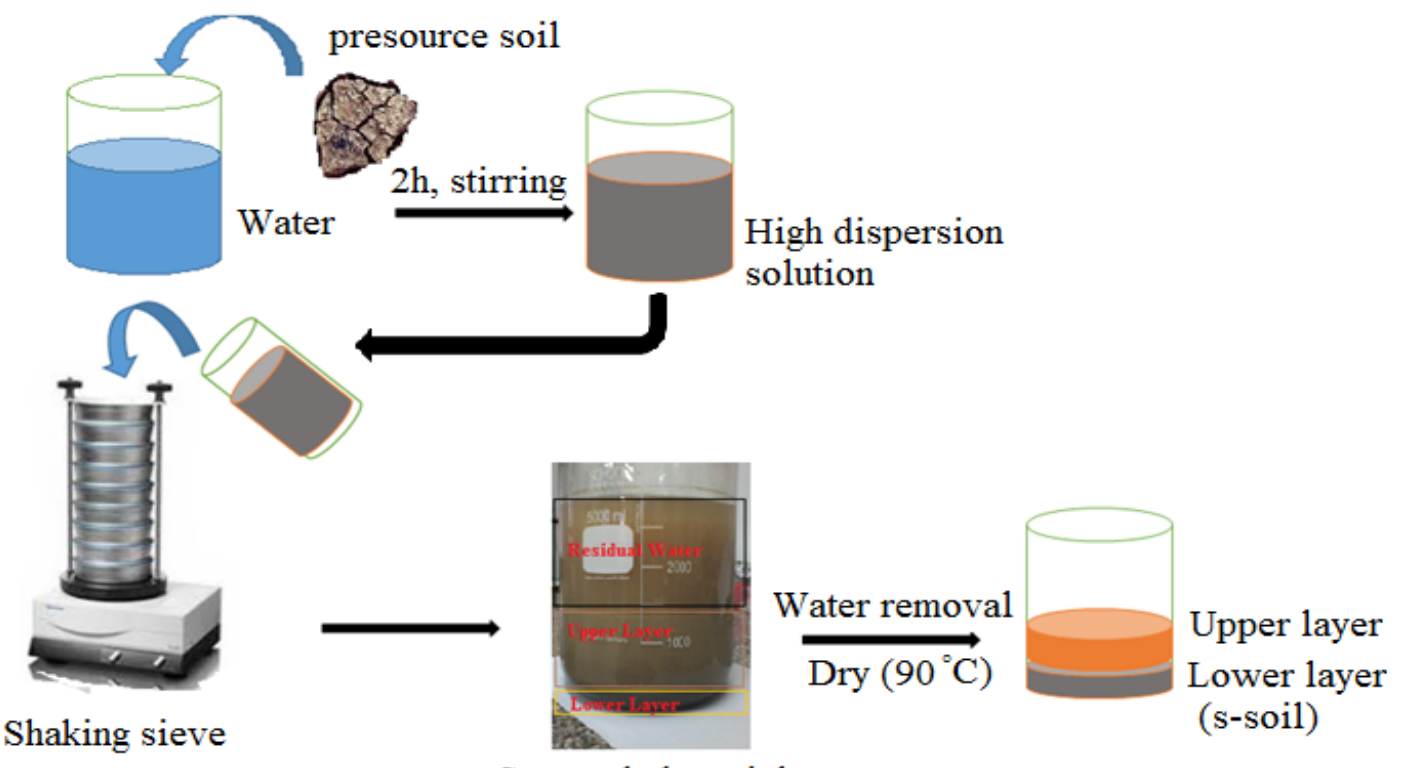

Suspended particles

Scheme 1. The schematic diagram of the experimental process.
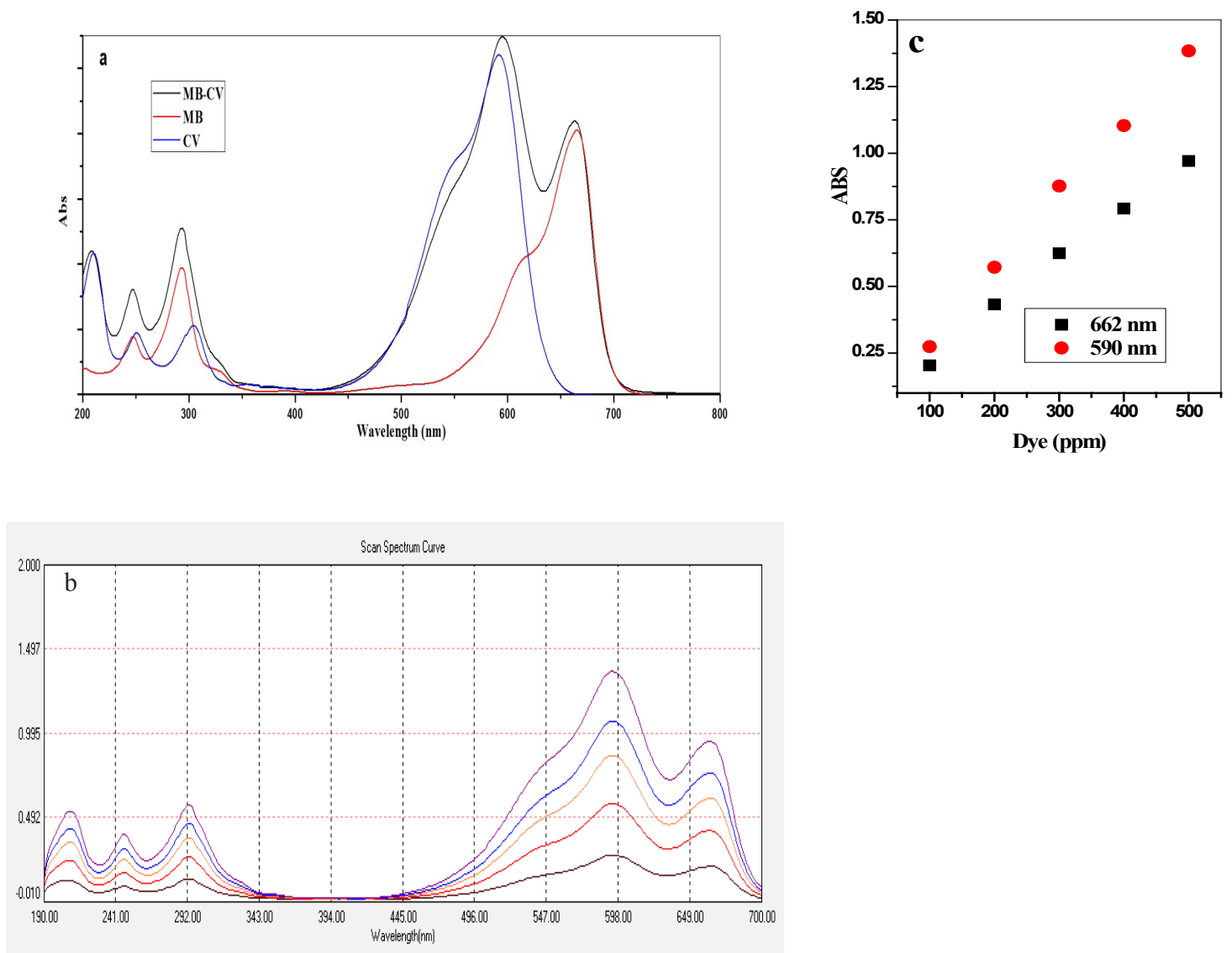

Fig. 1. a) UV-spectrum, b) The dilution of the dye solution in the binary system and c) The calibration curve of $\mathrm{MB}$ and CV dyes. 
reduction of both dyes in the binary system.

Figure 1c illustrates the calibration curve in the UV-Vis spectrometer for MB\&CV dye in the binary system. The figure indicated that there is a relationship (linear) between the absorbance and the concentration for the two dyes in the binary.

\section{Characterization}

Figure 2 (a-c) illustrates the SEM image for surface morphology and the approximate size of the s-soil. The soil particles appear distributed inhomogeneously with irregular shape particles which leads to increase of the absorption surface area. Table 1 shows the composition of pr-soil and s-soil by EDX analysis. The data show the presence of $\mathrm{Al}, \mathrm{O}, \mathrm{Si}, \mathrm{Na}, \mathrm{K}, \mathrm{Mg}, \mathrm{Ca}, \mathrm{Fe}$ and $\mathrm{Ti}$, elements were eonfirmed in both pr-soil and s-soil with a small variation in $\mathrm{Al} \%$ values.

Figure 2d show the FTIR spectra of pr-soil, s-soil, MB, CV, and s-soil adsorbed dye. The pr-

TABLE 1. EDX analysis of pr-soil and s-soil. soil and s-soil show characteristic M-O vibration peaks at 1024 and $764 \mathrm{~cm}^{-1}(\mathrm{M}=\mathrm{Si}, \mathrm{Fe}, \mathrm{Mg}, \mathrm{Ti}$, $\mathrm{Al}$ and $\mathrm{Ca}$ ). The gotten peak values have a good agreement with the literature [37]. Furthermore, the absorption peak at $467 \mathrm{~cm}^{-1}$ is related to the $\mathrm{M}-\mathrm{O}-\mathrm{M}$ [38]. The wide absorption peak in the range of $3431 \mathrm{~cm}^{-1}$ corresponds to $-\mathrm{OH}$ group and this designates the presence of water (absorbed) on the nanoparticles' surface [38, 39]. Furthermore, the figure shows the characteristic bands for both $\mathrm{MB}$ and CV dyes in its solid state. But, the typical bands of those dyes have been overlapped with the M-O bands of the adsorbent. Those results have been reported [40].

Figure 2e illustrates the XRD patterns of the pr-soil and s-soil. Pr-soil exhibited fine and intense peaks at $2 \theta=21.1^{\circ}$ and $27.4^{\circ}$, which are characteristic of crystallized material with more noise along X-ray diffractogram. Moreover, the XRD pattern of s-soil represents sharp, intense peaks at $2 \theta=21.5^{\circ}, 27.4^{\circ}$, and $50.8^{\circ}$ with more

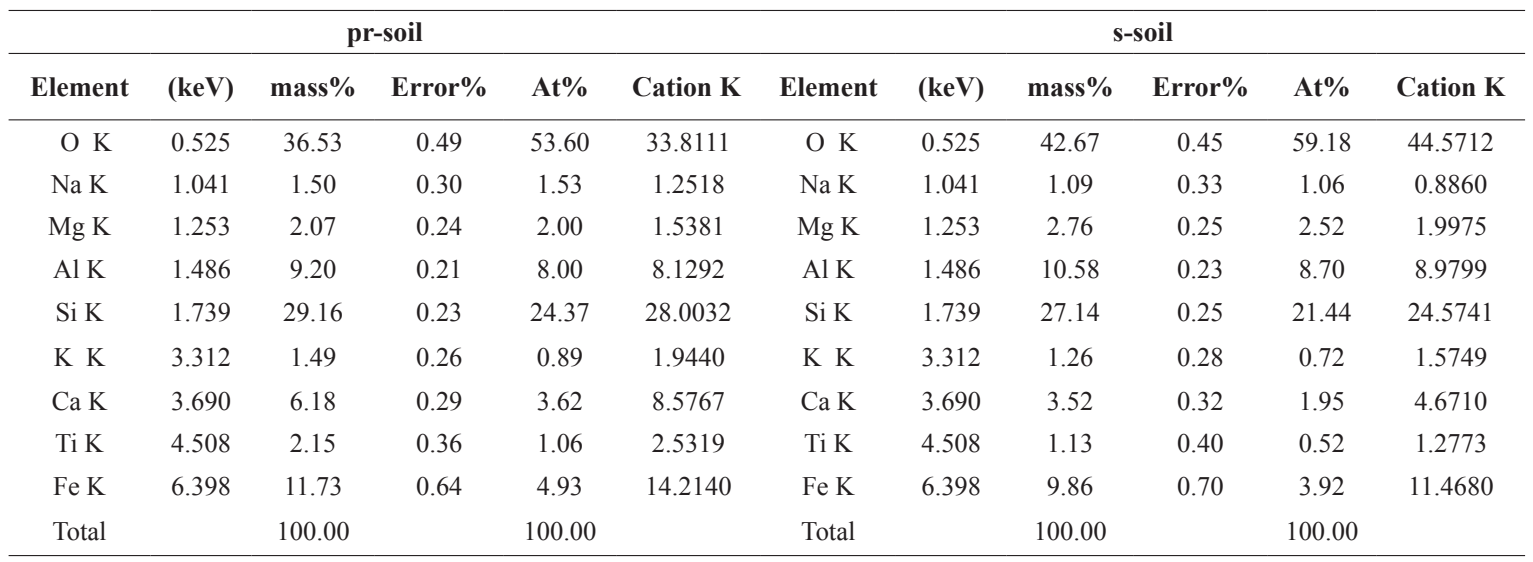

smoothing diffractogram. The X-ray diffraction spectrum of pr-soil displays the existence of the two main strong peaks at $21.00^{\circ}$ and $27.00^{\circ}$ that match two respective (004) and (202) images of calcium aluminum silicate phase in the samples [41].

\section{Adsorption parameters \\ Dye concentration effect}

Figure 3(a,d) represent the removal percent $(\% \mathrm{R})$ variation versus the contact time. The results show that $\% \mathrm{R}$ (for both dyes) increased quickly during the first two minutes of contact between the two phases. This refers to the plentiful accessibility of active sites on the sorbent. After that, the $\% \mathrm{R}$ reaches steady state after $10 \mathrm{~min}$ and the sorption process becomes less effective due to the regular occupancy of the active sites [42].

Each the constants and model parameters values were calculated and provided in Tables $(2,3)$ and Fig. 3(c-f). The information obtained shows that the pseudo-first-order fail to represent this test because of the low agreement between experimental \& theoretical adsorption capacity $\mathrm{q}_{\mathrm{e}}$, additionally, the low values of $\mathrm{R}^{2}$. This confirms that the model was unsuitable for determining the s-soil kinetics. On the other hand, pseudo-secondorder model $\mathrm{R}^{2}$ values declare that the adsorption procedure followed the kinetics of pseudosecond-order model at initial dye concentrations. Moreover, the data demonstrate that the adsorption of dyes onto the adsorbent surface following 

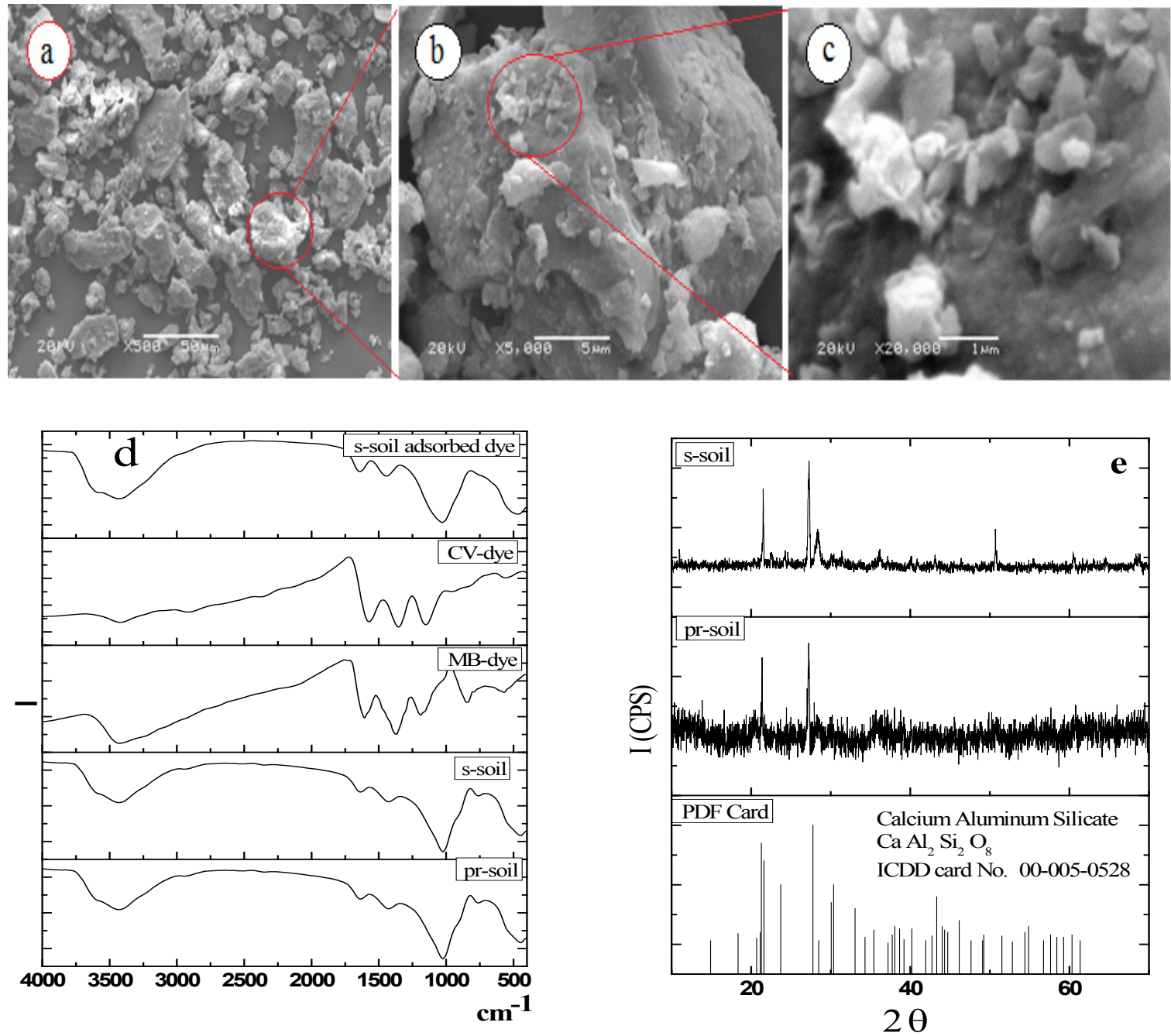

Fig. 2. SEM images of s-soil (a-c) at different magnification, (d) FTIR spectrum of pr-soil and s-soil, and (e) XRD diffraction patterns of pr-soil and s-soil.

TABLE 2. Pseudo-First-order and Second-order kinetic models for dye various concentration.

\begin{tabular}{|c|c|c|c|c|c|c|c|c|}
\hline \multirow[b]{2}{*}{ Dye } & \multirow{2}{*}{$\begin{array}{l}\text { Concentration } \\
(\mathrm{ppm})\end{array}$} & \multirow{2}{*}{$\underset{\left.\mathrm{g}^{-1}\right)}{\mathrm{q}_{\mathrm{eexp}}(\mathrm{mg}}$} & \multicolumn{3}{|c|}{ First-order kinetic parameter } & \multicolumn{3}{|c|}{ Second-order kinetic parameter } \\
\hline & & & $\mathrm{K}_{\mathrm{ads}}\left(\mathrm{min}^{-}\right.$ & $\begin{array}{c}\mathrm{q}_{\mathrm{e} \text { cal }}(\mathrm{mg} \\
\left.\mathrm{g}^{-1}\right)\end{array}$ & $\mathrm{R}^{2}$ & $\underset{\mathrm{K}_{\text {ads }}\left(\mathrm{g} \mathrm{mg}^{-}\right.}{\left.{ }^{1} \mathrm{~min}^{-1}\right)}$ & $\begin{array}{c}\mathrm{q}_{\mathrm{e} \mathrm{cal}}(\mathrm{mg} \\
\left.\mathrm{g}^{-1}\right)\end{array}$ & $\mathrm{R}^{2}$ \\
\hline \multirow{5}{*}{ MB } & 100 & 19.80 & -6.90 & 3.60 & 0.866 & 4.53 & 20.00 & 0.997 \\
\hline & 200 & 36.03 & -0.51 & 12.88 & 0.952 & 0.20 & 37.03 & 0.990 \\
\hline & 300 & 45.02 & -0.32 & 16.60 & 0.852 & 0.12 & 45.45 & 0.993 \\
\hline & 400 & 44.24 & -0.51 & 17.00 & 0.805 & 0.14 & 45.45 & 0.992 \\
\hline & 500 & 46.86 & -0.28 & 13.80 & 0.695 & 0.13 & 47.62 & 0.994 \\
\hline \multirow{5}{*}{$\mathrm{CV}$} & 100 & 19.6 & -2.23 & 3.80 & 0.880 & 0.71 & 20.00 & 0.996 \\
\hline & 200 & 32.24 & -0.46 & 33.88 & 0.910 & 0.24 & 33.33 & 0.995 \\
\hline & 300 & 35.7 & -0.37 & 11.22 & 0.710 & 0.56 & 35.71 & 0.999 \\
\hline & 400 & 32.97 & -0.44 & 14.45 & 0.570 & 0.37 & 34.48 & 0.996 \\
\hline & 500 & 37.28 & -0.12 & 9.77 & 0.170 & 0.19 & 37.04 & 0.997 \\
\hline
\end{tabular}

Egypt. J. Chem. 62, No. 3 (2019) 
TABLE 3. Calculated equilibrium constants for adsorption of MB and CV on s-soil.

\begin{tabular}{cccccccc}
\hline \multirow{2}{*}{ Dye } & \multicolumn{3}{c}{ Langmuir isotherm model } & \multicolumn{3}{c}{ Freundlich isotherm model } \\
\cline { 2 - 8 } & $\mathbf{q}^{\mathbf{0}}\left(\mathbf{m g ~ \mathbf { g } ^ { - 1 }}\right)$ & $\mathbf{b}\left(\mathbf{m g}^{-1}\right)$ & $\mathbf{R}_{\mathbf{L}}$ & $\mathbf{R}^{\mathbf{2}}$ & $\mathbf{1 / n}$ & $\mathbf{K}_{\mathbf{f}}\left(\mathbf{m} \mathbf{~ g ~}^{-1}\right)$ & $\mathbf{R}^{\mathbf{2}}$ \\
\hline MB & 47.62 & 0.23 & 0.042 & 0.99 & 0.093 & 4.26 & 0.97 \\
CV & 35.71 & 0.22 & 0.043 & 0.99 & 0.13 & 3.56 & 0.99 \\
\hline
\end{tabular}
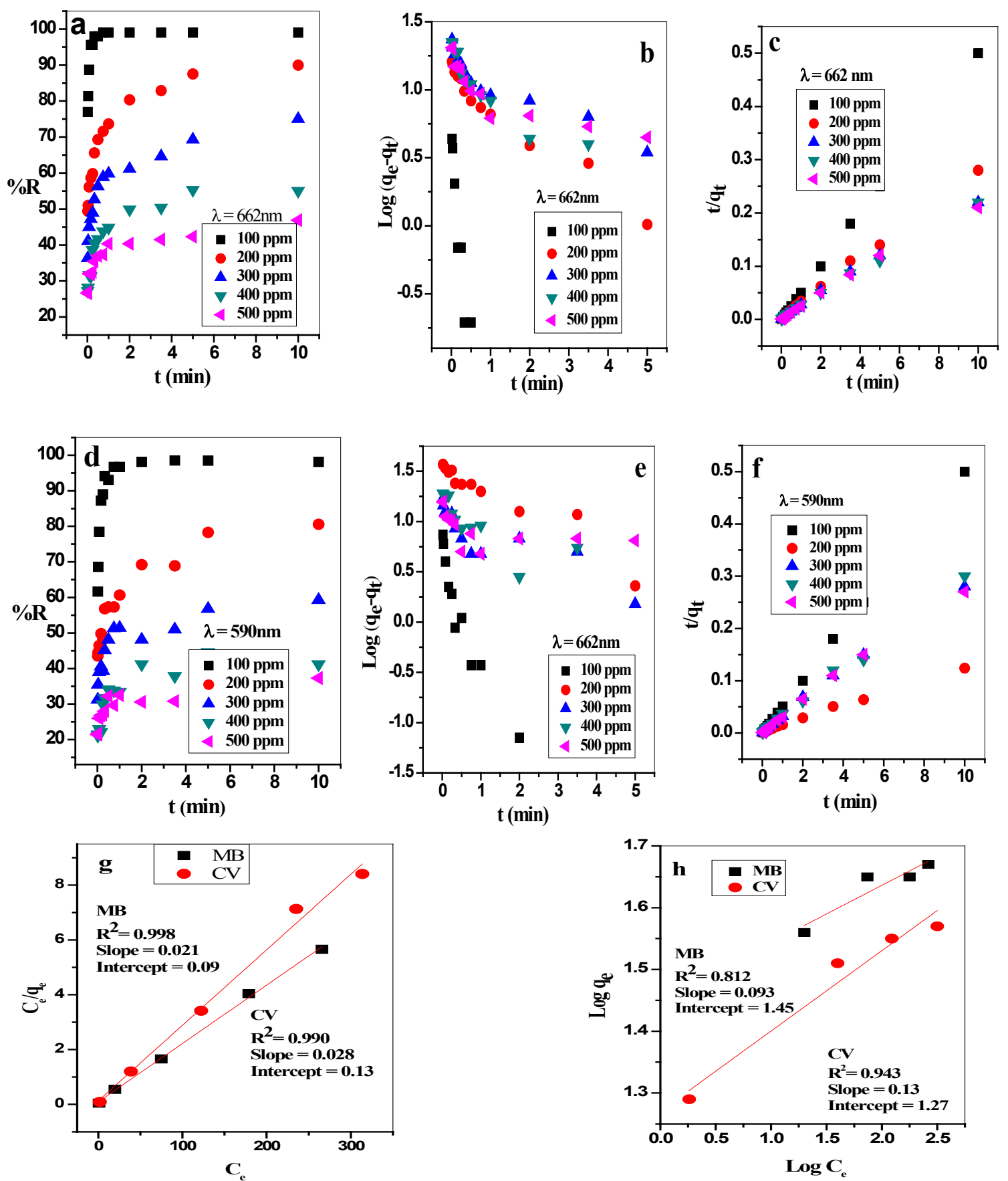

Fig. 3. Effect of $\mathrm{MB}$ and $\mathrm{CV}$ dyes concentration on (a, d) dye removal percent (\%R); (b, e) pseudo-First-order kinetic model; (c, f) pseudo-Second-order kinetic model, respectively; (g) Langmuir and (h) Freundlich model (s-soil dose $=0.1 \mathrm{~g} / 20 \mathrm{ml}, \mathrm{pH}=7$ and $\mathrm{T}=25^{\circ} \mathrm{C}$ ). 
a pseudo-second-order reaction as $\mathrm{q}_{\mathrm{e}}$ values (experimentally) are in conformity with the $q_{e}$ values (calculated). Furthermore, the $\mathrm{k}_{\text {ads }}$ values (pseudo-second-order rate constant) were reduced by increasing concentration of absorbing dye in solution suggesting an absorption rate decreasing. This is apparently owing to the fast growth of positive charge on the surface - for initial uptakeof the dye on the surface of adsorbent, which prevents more dye uptake at the subsequent steps of reacting by columbic repulsion force. Almost these results designated that s-soil can be utilized to eliminate the dye successfully from solutions through monolayer mechanism.

Moreover, the dyes adsorption equilibrium isotherm was calculated (Tables 2, 3). The tables illustrate that the ultimate adsorption for $\mathrm{MB}$ and $\mathrm{CV}$ onto s-soil from binary solution were 47.62 and $35.71 \mathrm{mg} \mathrm{g}^{-1}$, respectively. Also, the adsorption process of these dyes was founded to be fitted by the Langmuir model. In conclusion, the monolayer adsorption process happens onto the adsorbent surface and these agree with other work [43].

The $\mathrm{R}_{\mathrm{L}}$ (separation parameter) was: 0.042 (for $\mathrm{MB}$ ) and 0.043 (for $\mathrm{CV}$ ) for the initial concentration of dyes (100-500 ppm). Those values are designating their favorable adsorption upon adsorbent as it is within the range of $0-1$. The $1 / \mathrm{n}$ numerical values are 0.13 and 0.09 for $\mathrm{CV}$ and $\mathrm{MB}$, respectively. However, those values are less than the unit, which strongly supported favorable adsorption by the adsorbent overall studied adsorbent concentration.

\section{Soil dose effect}

CV\&MB removal percent from the water solution in the binary system form was also investigated using different amounts of adsorbent.
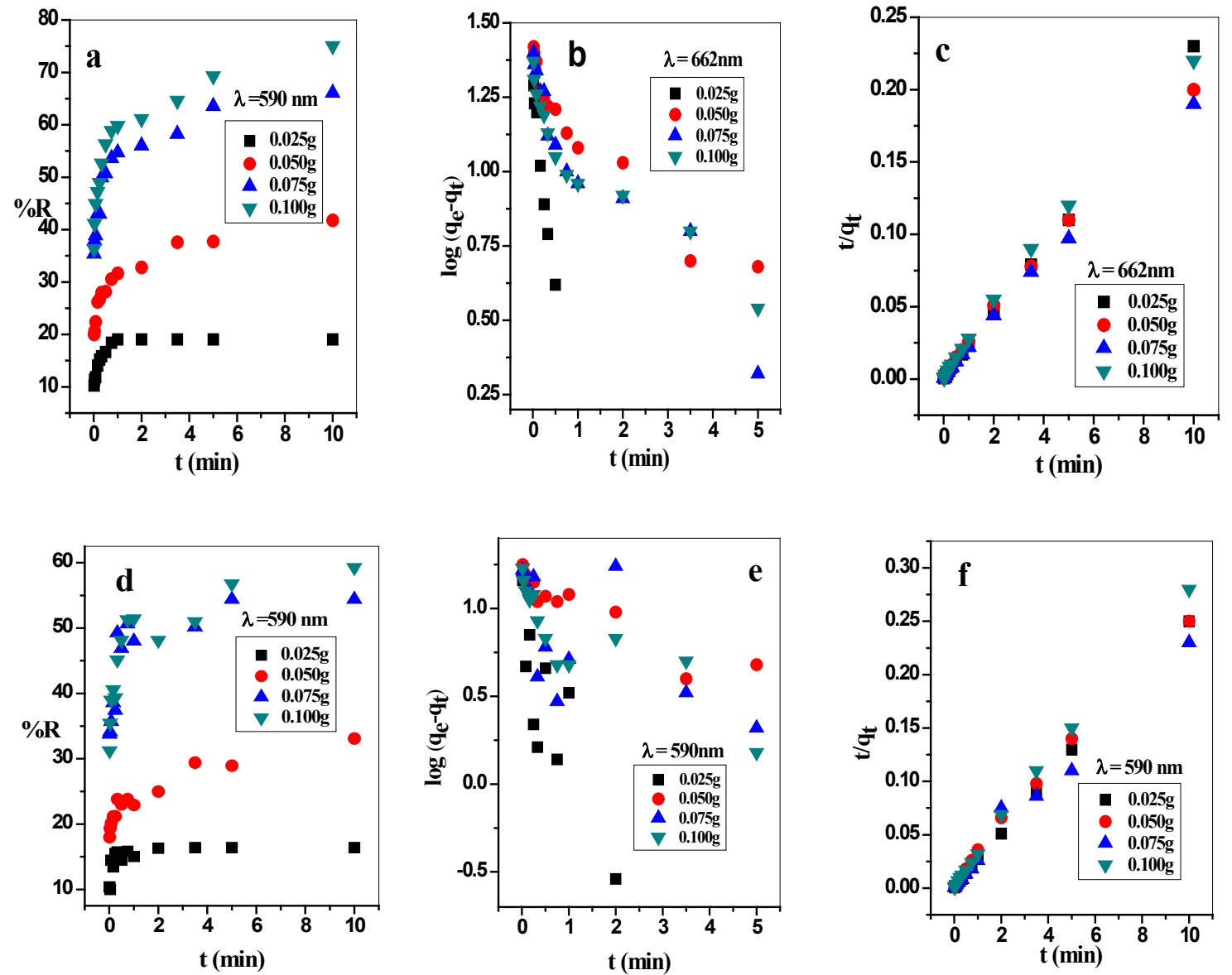

Fig. 4. Effect of dose concentration $(\mathrm{g} / 20 \mathrm{ml})$ on adsorption process for both dyes $\mathrm{MB}$ and $\mathrm{CV}$, (a, d) dye removal percent (\%R); (b, e) pseudo-First-order kinetic model; (c, f) pseudo-Second-order kinetic model, respectively (dye concentration $=300 \mathrm{ppm}, \mathrm{pH}=7$ and $\mathrm{T}=25^{\circ} \mathrm{C}$ ).

Egypt. J. Chem. 62, No. 3 (2019) 
The removal process is highly affected by the amount of the contacting sorbent in the aqueous phase [44]. Figure 4(a, d) illustrates that removal percent of the dyes rapidly increased by increasing the adsorbent dose for both dyes at the first 2 min. After that $\% \mathrm{R}$ reach steady state and this agreement with another work [45].

The acquired $\mathrm{R}^{2}$ values (correlation coefficients) for the linear plot of $t$ /qt versus $t$ of pseudo-second-order equation for the dyes (Fig. 4 b, e) greater than that belongs to the pseudo-firstorder (Fig. 4 c, f). It was found that the adsorption kinetics were better fitted by pseudo-second-order kinetic model. In addition, Table 4 demonstrates that the $q_{e}$ values (experimental) agree totally with the calculated $\mathrm{q}_{e}$ values. This indicates that the adsorption process -on s-soil- for both dyes follows the second-order kinetics.

\section{Initial $\mathrm{pH}$ effect}

Figure 5(a,d) introduce the removal percent of both dyes at different $\mathrm{pH}$. The results prove that $\mathrm{R} \%$ increase quickly within the first $2 \mathrm{~min}$ and appears to be constant after this time for all the solution $\mathrm{pH}$ values. Dyes adsorption increases at $\mathrm{pH}$ values 3.7 and 7 while a decrease in $\mathrm{pH}$ values 2 and 8.7. Minor adsorption of $\mathrm{CV}$ and $\mathrm{MB}$ at an acidic $\mathrm{pH}$ may be referred to the existence of excess $\mathrm{H}^{+}$ions occupying the adsorbent active sites which preventing adsorption of the dye [46]. In addition, the above behaviour can come from the electric layer polarity change on both the silica and alumina contents of the clay from positive to negative charge. These changes improve cationic dye removal from its aqueous solution by attracting the dye cations. Furthermore, the hydroxylated oxides acid-base dissociation of the clay followed by ion exchange with the dye cations could be responsible for the maximum removal of the cationic dye from its solution. Above $\mathrm{pH} 7$, the density of negative charge on the surface of the adsorbent decreased, this led to a slow decline in the clay removal ability. Yet, between $\mathrm{pH}$ values 3.5 and 7 , the removal percent nearly the same indicates that the presence of high concentrations of hydronium ions does not influence the kinetics of adsorption and consequently, the removal is at its maximum.

Figure 5(b,e) and 5(c,f) represent plotting of the pseudo-first-order and pseudo-second-order adsorption kinetic models at various $\mathrm{pH}$ values for both $\mathrm{CV}$ and $\mathrm{MB}$ dyes, respectively. The calculated correlation coefficients and kinetic parameters were obtained are listed in Table 5. The table and figure data demonstrated that pseudo-second-order adsorption kinetic models fitted well with the experimental data depending on calculated $\mathrm{R}^{2}(>0.990)$ and $\mathrm{q}_{\mathrm{e}}$ values.

(b, e) pseudo-First-order kinetic model; (c, f) pseudo-Second-order kinetic model, respectively

\section{Temperature effect}

Figure 6 displays the temperature effect on the $\mathrm{MB}$ and $\mathrm{CV}$ adsorption on the adsorbents. It can be seen that uptake percent increases rapidly at earlier steps of adsorption and the removal percent reaches to equilibrium overall temperature values.

Figure $6(\mathrm{~b}, \mathrm{e})$ and $6(\mathrm{c}, \mathrm{f})$ display the linear relation of pseudo-first-order and pseudo-secondorder adsorption kinetic models for $\mathrm{CV}$ and $\mathrm{MB}$ dyes, respectively. Table 6 illustrates the calculated values of $q_{e}$ and $R^{2}$. The obtained $R^{2}$ values

TABLE 4. Calculated parameters of the pseudo First-order and pseudo Second-order kinetic models for various s-soil doses.

\begin{tabular}{|c|c|c|c|c|c|c|c|c|}
\hline \multirow[b]{2}{*}{ Dye } & \multirow{2}{*}{$\begin{array}{c}\text { Adsorbent } \\
\text { dose (g) }\end{array}$} & \multirow{2}{*}{$\underset{q_{e \exp }(m g}{\left.g^{-1}\right)}$} & \multicolumn{3}{|c|}{ First-order kinetic parameter } & \multicolumn{3}{|c|}{ Second-order kinetic parameter } \\
\hline & & & $K_{\text {ads }}\left(\min ^{-1}\right)$ & $\mathrm{q}_{\mathrm{e} \mathrm{cal}}\left(\mathrm{mg} \mathrm{g}^{-1}\right)$ & $\mathbf{R}^{2}$ & $\underset{\mathbf{K}_{\text {ads }}(\mathbf{g ~ m g}}{\left.{ }^{1} \mathbf{m i n}^{-1}\right)}$ & 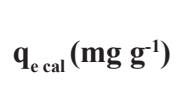 & $\mathbf{R}^{2}$ \\
\hline \multirow{4}{*}{ MB } & 0.025 & 44.16 & -3.25 & 19.00 & 0.978 & 1.24 & 43.50 & 0.999 \\
\hline & 0.050 & 50.11 & -0.35 & 20.40 & 0.897 & 0.10 & 50.00 & 0.996 \\
\hline & 0.075 & 53.52 & -0.41 & 19.00 & 0.875 & 0.15 & 52.60 & 0.998 \\
\hline & 0.100 & 45.02 & -0.32 & 16.60 & 0.852 & 0.12 & 45.45 & 0.995 \\
\hline \multirow{4}{*}{$\mathrm{CV}$} & 0.025 & 39.41 & -0.28 & 14.80 & 0.856 & 0.11 & 40.00 & 0.994 \\
\hline & 0.050 & 39.60 & -0.32 & 10.72 & 0.333 & 0.15 & 43.50 & 0.984 \\
\hline & 0.075 & 43.96 & -0.37 & 11.22 & 0.709 & 0.19 & 35.71 & 0.997 \\
\hline & 0.100 & 35.70 & -1.61 & 7.60 & 0.658 & 0.11 & 40.00 & 0.999 \\
\hline
\end{tabular}



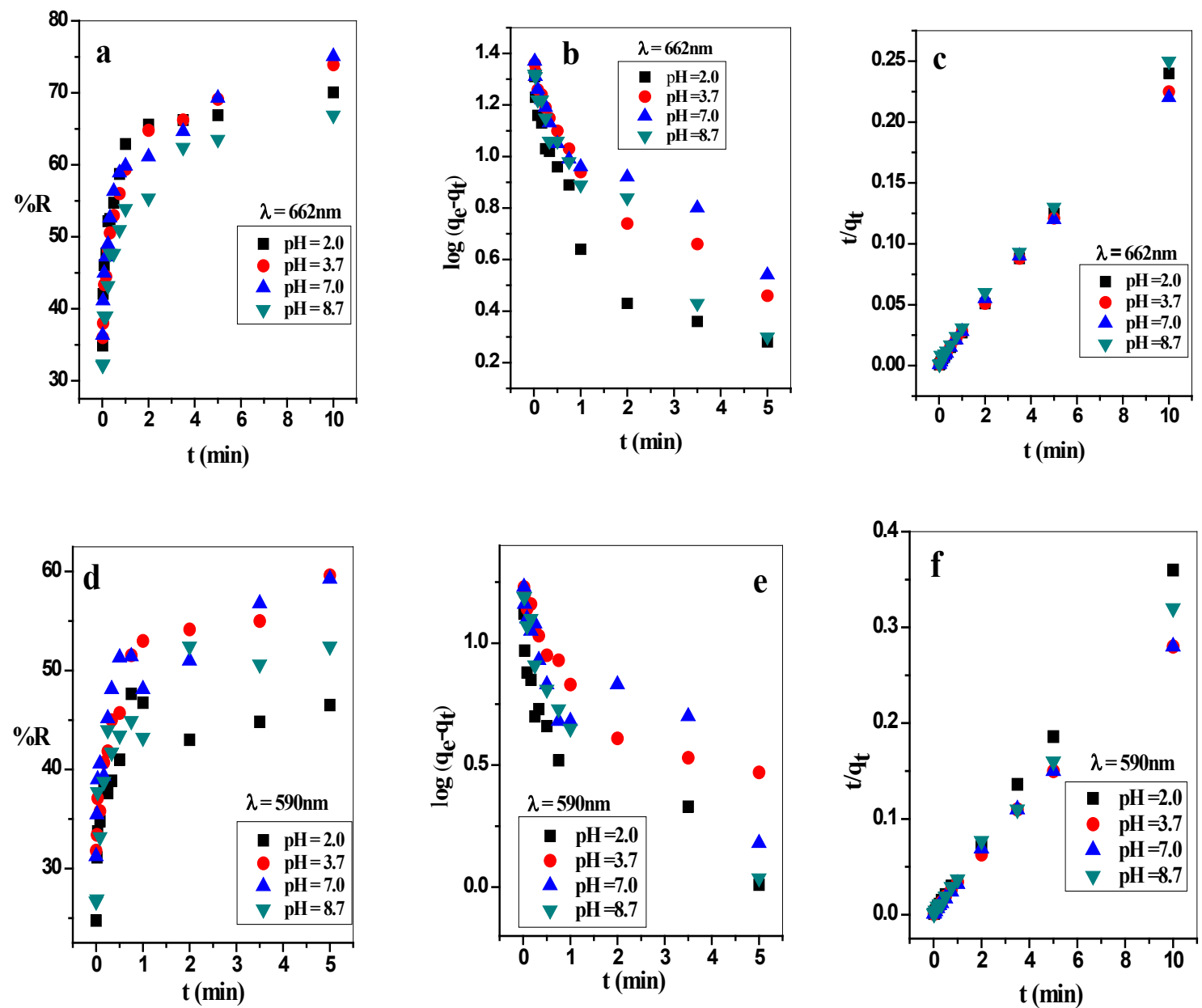

Fig. 5. Effect of the $\mathrm{pH}$ on adsorption process for both dyes $\mathrm{MB}$ and $\mathrm{CV},(\mathrm{a}, \mathrm{d})$ dye removal percent $(\% \mathrm{R})$; (b, e) pseudo-First-order kinetic model; $(c, f)$ pseudo-Second-order kinetic model, respectively (dye concentration $=300 \mathrm{ppm}, \mathrm{s}$-soil dose $=0.1 \mathrm{~g} / 20 \mathrm{~mL}$ and $\mathrm{T}=25^{\circ} \mathrm{C}$ ).

TABLE 5. Calculated parameters of the pseudo First-order and pseudo Second-order kinetic models for different pH values.

\begin{tabular}{|c|c|c|c|c|c|c|c|c|}
\hline \multirow[b]{2}{*}{ Dye } & \multirow[b]{2}{*}{ PH } & \multirow{2}{*}{$\underset{\mathrm{q}_{\mathrm{exp}}}{\left.\mathrm{g}^{-1}\right)}$} & \multicolumn{3}{|c|}{ First-order kinetic parameter } & \multicolumn{3}{|c|}{ Second-order kinetic parameter } \\
\hline & & & $\mathbf{K}_{\text {ads }}\left(\mathbf{m i n}^{-1}\right)$ & $\begin{array}{c}\mathbf{q}_{\mathrm{e} \mathrm{cal}}(\mathrm{mg} \\
\left.\mathrm{g}^{-1}\right)\end{array}$ & $\mathbf{R}^{2}$ & $\begin{array}{c}\mathrm{K}_{\text {ads }} \\
\left(\mathrm{g} \mathrm{mg}^{-}\right. \\
\left.{ }^{1} \mathbf{m i n}^{-1}\right) \\
\end{array}$ & $q_{e \text { cal }}\left(m g g^{-1}\right)$ & $\mathbf{R}^{2}$ \\
\hline \multirow{4}{*}{ MB } & 2 & 42.05 & -0.46 & 12.60 & 0.798 & 0.25 & 41.70 & 0.999 \\
\hline & 3.7 & 44.35 & -0.39 & 17.00 & 0.896 & 0.14 & 43.50 & 0.998 \\
\hline & 7 & 45.02 & 0.32 & 17.00 & 0.852 & 0.12 & 45.45 & 0.995 \\
\hline & 8.7 & 40.13 & -0.46 & 16.22 & 0.932 & 0.14 & 40.00 & 0.998 \\
\hline \multirow{4}{*}{$\mathrm{CV}$} & 2 & 27.91 & -0.39 & 7.24 & 0.803 & 0.17 & 35.71 & 0.998 \\
\hline & 3.7 & 35.92 & -0.35 & 12.60 & 0.837 & 0.20 & 35.71 & 0.997 \\
\hline & 7 & 35.70 & -0.37 & 11.22 & 0.709 & 0.33 & 31.25 & 0.998 \\
\hline & 8.7 & 31.47 & -0.47 & 11.00 & 0.851 & 0.65 & 27.78 & 0.999 \\
\hline
\end{tabular}

Egypt. J. Chem. 62, No. 3 (2019) 

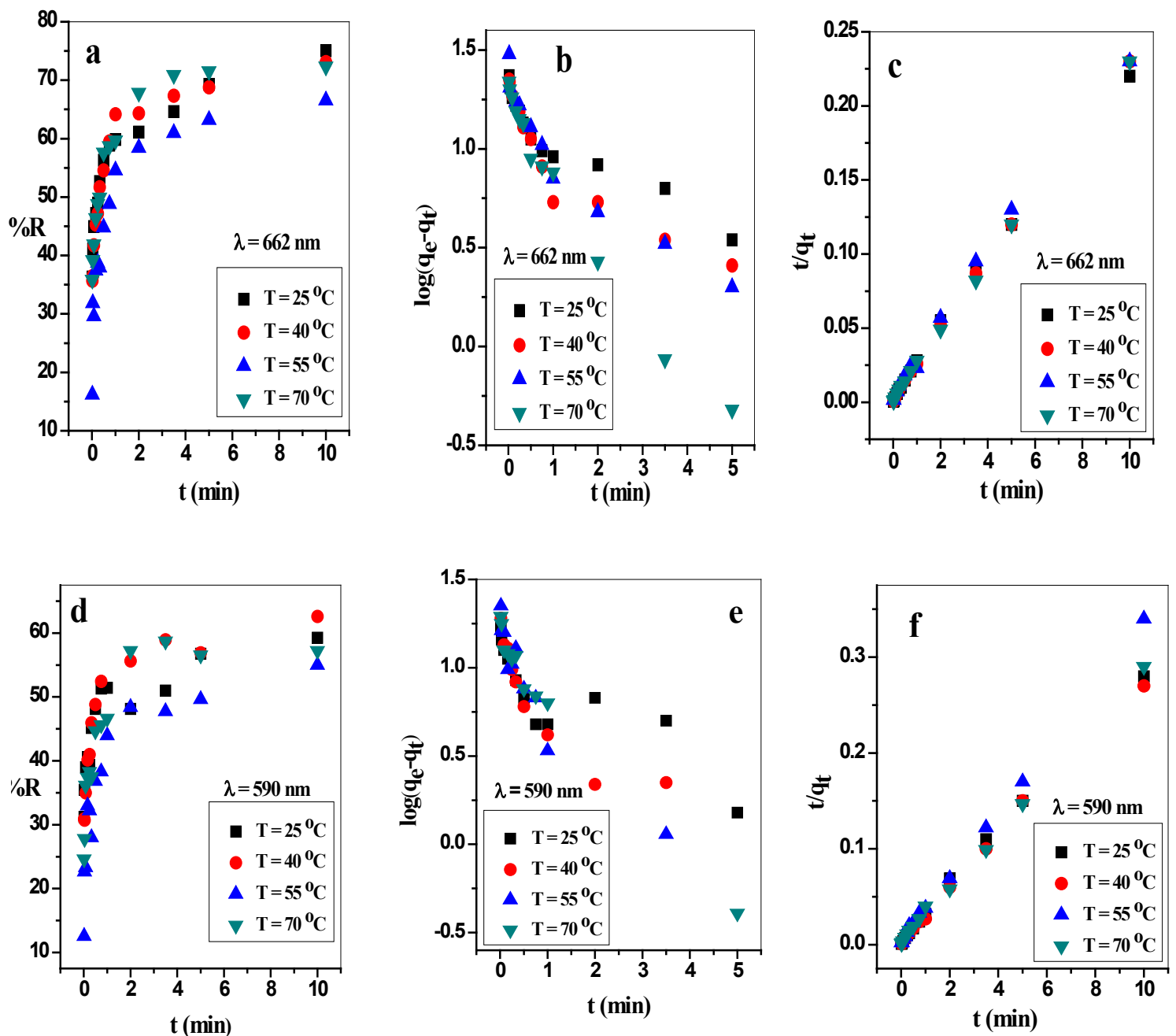

Fig. 6. Effect of temperature on adsorption process for both dyes $\mathrm{MB}$ and $\mathrm{CV}$, (a, d) dye removal percent $(\% \mathrm{R})$; (b, e) pseudo-First-order kinetic model; (c, f) pseudo-Second-order kinetic model, respectively (dye concentration $=300 \mathrm{ppm}, \mathrm{s}-\mathrm{soil}$ dose $=0.1 \mathrm{~g} / 20 \mathrm{~mL}$ and $\mathrm{pH}=7$ ).

TABLE 6. Calculated parameters of the pseudo First-order and pseudo Second-order kinetic models at different temperatures.

\begin{tabular}{|c|c|c|c|c|c|c|c|c|}
\hline \multirow[b]{2}{*}{ Dye } & \multirow[b]{2}{*}{$\mathbf{T}\left({ }^{\circ} \mathbf{C}\right)$} & \multirow{2}{*}{$\underset{\left.\mathrm{g}^{-1}\right)}{q \mathrm{e}_{\exp }(\mathrm{mg}}$} & \multicolumn{3}{|c|}{ First-order kinetic parameter } & \multicolumn{3}{|c|}{ Second-order kinetic parameter } \\
\hline & & & $\underset{\left(\mathbf{m i n}^{-1}\right)}{\mathbf{K}_{\mathrm{ads}}}$ & $\begin{array}{c}\mathbf{q}_{\text {e cal }}(\mathbf{m g} \\
\left.\mathrm{g}^{-1}\right)\end{array}$ & $\mathbf{R}^{2}$ & 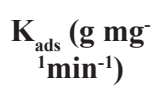 & $\begin{array}{c}\mathbf{q}_{\mathrm{ecal}}(\mathbf{m g} \\
\left.\mathrm{g}^{-1}\right)\end{array}$ & $\mathbf{R}^{2}$ \\
\hline \multirow{4}{*}{ MB } & 25 & 45.02 & -0.32 & 17.00 & 0.852 & 0.12 & 45.45 & 0.993 \\
\hline & 40 & 43.87 & -0.40 & 13.00 & 0.811 & 0.10 & 43.50 & 0.999 \\
\hline & 55 & 40.20 & -0.47 & 17.78 & 0.881 & 0.13 & 43.00 & 0.995 \\
\hline & 70 & 43.39 & -0.78 & 17.00 & 0.970 & 0.17 & 43.50 & 0.999 \\
\hline \multirow{4}{*}{$\mathrm{CV}$} & 25 & 35.70 & -0.37 & 11.22 & 0.709 & 0.20 & 35.71 & 0.997 \\
\hline & 40 & 37.56 & -0.60 & 11.23 & 0.750 & 0.24 & 37.00 & 0.997 \\
\hline & 55 & 29.77 & -0.78 & 13.80 & 0.851 & 0.29 & 29.41 & 0.999 \\
\hline & 70 & 34.34 & -0.71 & 14.00 & 0.970 & 0.23 & 34.83 & 0.998 \\
\hline
\end{tabular}


from pseudo-first-order and pseudo-secondorder adsorption model are $\leq 0.990$ and $\geq 0.990$, respectively. Moreover, the calculated values of $\mathrm{q}_{\mathrm{e}}$ match highly effective with the experimental data. This suggests that the kinetic modeling of the temperature effect on the adsorption process is more likely fits to the models of the pseudosecond-order adsorption.

\section{Conclusion}

In the present study, the settling technique appears to be effective in the fractionation of local soil clay. The crystal violet and methylene blue dyes (in a binary system) successfully removed from aqueous medium over a soil sample (s-soil) fractioned from a local soil sample (pr-soil). The reaction between the dye species and the soil particles show fast adsorption kinetics. Referring to the $\mathrm{q}_{\mathrm{e}}$ and $\mathrm{R}^{2}$ values the pseudo-second-order model more fitted the adsorption kinetics process. According to Langmuir isotherm, the obtained soil can adsorb 47.82 and $35.71 \mathrm{mg} \mathrm{g}^{-1}$ for $\mathrm{MB}$ and $\mathrm{CV}$. Those results give a promising solution for crystal violet and methylene blue dye removal from wastewater.

\section{References}

1. Valipour, M., How do different factors impact agricultural water management, Open Agriculture 1, 89-111 (2016).

2. Ihsanullah, A. A., Al-Amer, A.M., Laoui, T., Al-Marri, M.J., Nasser, M.S., Khraisheh, M., Atieh, M.A., Heavy metal removal from aqueous solution by advanced carbon nanotubes: Critical review of adsorption applications. Separation and Purification Technology, 157, 141 -161 (2016).

3. Abd El-Hamid, A. I., Aly, H. F., Removal of Fe (III) from Aqueous Solution Using Thiosalcylic Acid as An Efficient Adsorbent. Egypt Journal of Chemistry, 61, 617-627 (2018).

4. Chakraborty, S., De, S., Basu, J.K., Das, G.S., Treatment of a textile effluent: application of a combination method involving adsorption and nanofiltration. Desalination 174, 73-85 (2005).

5. Erol, F., Ozbelge, T.A., Catalytic ozonation with non-polar bonded alumina phases for treatment of aqueous dye solutions in a semi-batch reactor. Chemical Engineering Journal, 139, 272-283 (2008).

6. Belkacem, M., Khodir, M., Abdelkrim, S., Treatment characteristics of textile wastewater and removal of heavy metals using the electroflotation technique, Desalination 228, 245-254 (2008).

7. Chawla, S., Uppal, H., Yadav, M., Bahadur, N., Singh, N., Zinc peroxide nanomaterial as an adsorbent for removal of Congo red dye from waste water, Ecotoxicology and Environmental Safety, 135, 68 -74 (2017).

8. Asmara, S. H., Sayed, A. A., Nahla, M. M., Mostafa, K., Adsorption of chromium (VI) from aqueous solution by glycine modified cross-linked chitosan resin. Egypt. Journal of Chemistry, 61, 530-540 (2018).

9. Liu, X., Yan, L., Yin, W., Zhou, L., Tian, G., Shi, J., Yang, Z., Xiao, D., Gu, Z., Zhao, Y., A magnetic graphene hybrid functionalized with beta-cyclodextrins for fast and efficient removal of organic dyes. Journal of Material Chemistry A 2, $12296-12303$ (2014).

10. Deepak, R., Radhey, S.S., Swagata, K., Lakhbeer, S.A., Vandana, M., Ecotoxic potential of a presumably non-toxic azo dye. Ecotoxicology and Environmental Safety, 148, 528-537 (2018).

11. Robinson, T., Chandran, B., Nigam, P., Removal of dyes from a synthetic textile dye effluent by biosorption on apple pomace and wheat straw, Water Research 36, 2824-2830 (2002).

12. Mahmoodi, N.M., Arami, M., Bahrami, H., Khorramfar, S., The effect of $\mathrm{pH}$ on the removal of anionic dyes from colored textile wastewater using a biosorbent, Journal of Applied Polymer Science 120, 2996-3006 (2011).

13. Kayan, B., Gozmen, B., Demirel, M., Gizir, A.M., Degradation of acid red 97 dye in aqueous medium using wet oxidation and electro-Fenton techniques, Journal of Hazardous Materials, 177, $95-102$ (2010).

14. Tunay, O., Kabdasli, I., Eremektar, G., Orhon, D., Color removal from textile wastewaters. Water Science Technology, 34, 9-16 (1996).

15. Forgacs, E., Cserhati, T., Oros, G., Removal of synthetic dyes from wastewaters: A review. Environmental International, 30, 953 -971 (2004).

16. Tehrani-Bagha, A.R., Mahmoodi, N.M., Menger, F.M., Degradation of a persistent organic dye from colored textile wastewater by ozonation. Desalination, 260, 34 -38 (2010).

17. Zhai, Q.Q., Bo, T., Hu, G.X., High photoactive and visiblelight responsive raphene/titanate nanotubes 
photocatalysts: preparation and characterization. Journal of Hazardous Materials, 198, 78 -86 (2011).

18. Alventosa-deLara, E., Barredo-Damas, S., Alcaina-Miranda, M.I., Iborra-Clar, M.I., Ultrafiltration technology with a ceramic membrane for reactive dye removal: Optimization of membrane performance. Journal of Hazardous Materials, 209, $492-500$ (2012).

19. Ghaedi, M.; Hajati, S.; Barazesh, B.; Karimi, F.; Ghezelbash, G.: Saccharomyces cerevisiae for the biosorption of basic dyes from binary component systems and the high order derivative spectrophotometric method for simultaneous analysis of Brilliant green and Methylene blue. Journal of Industrial and Engineering Chemistry, 19, $227-233$ (2013b).

20. McKay, G., Blair, H.S., Gardner, J.R., Rate studies for the adsorption of dyestuffs on chitin. Journal of Colloidal Interface Science, 95, 108-119 (1983).

21. McKay, G., Analytical solution using a pore diffusion model for a pseudo irreversible isotherm for the adsorption of basic dye on silica. American Institute of Chemical Engineers Journal, 30, 692697 (1984)

22. Ho, Y.S., McKay, G., Sorption of dye from aqueous solution by peat. Chemical Engineering Journal, 70, 115-124 (1998).

23. Hameed, B.H., Spent tea leaves: a new nonconventional and low-cost adsorbent for removal of basic dye from aqueous solutions. Journal of Hazardous Materials, 161, 753-759 (2009).

24. Carmen, E., Mohamed, A., Sayed, M., Hager, A., Doaa, O., Renee, I. A., Yasser, M. M., Carbon nanotubes as superior sorbent for removal of phenol from industrial waste water. Egypt Journal of Chemistry, 61, 74-84 (2018).

25. Zawani, Z., Luqman, C.A., Choong, T.S.Y., Equilibrium, kinetics and thermodynamic studies: adsorption of remazol black 5 on the palm kernel shell activated carbon (PKS-AC). Europ Journal of Science Reseach, 37, 63-71 (2009).

26. Ahmad, R., Kumar, R., Adsorption studies of hazardous malachite green onto treated ginger waste. Journal of Environmental Management, 91, 1032-1038 (2010).

27. Bello, O.S., Ahmad, M.A., Adsorptive removal of a synthetic textile dye using coca pod husks. Journal of Toxicological \& Environmental
Chemistry, 93, 1298-1308 (2011).

28. Han, Y., Sheng, S., Yang, F., Xie, Y., Zhaoa, M., Li, J-R., Size exclusive and coordination-induced selective dye adsorption in a nanotubular metalorganic framework. Journal of Material Chemistry A, 3, 12804-12809 (2015).

29. Bu, R., Chen, F., Li, J., Li, W., Yang, F., Adsorption capability for anionic dyes on 2-hydroxyethyl ammonium acetate-intercalated layered double hydroxide. Colloids Surfaces A: Physicochemical and Engineering Aspects, 511, 312 -319 (2016).

30. Senthilkumaar, S., Varadarajan, P.R., Porkodi, K., Subbhuraam, C.V., Adsorption of methylene blue onto jute fiber carbon: Kinetics and equilibrium studies. J. Colloidal Interface Science, 284, 78-82 (2005).

31. Saeed, A., Sharif, M., Iqbal, M., Application potential of grapefruit peel as dye sorbent: kinetics, equilibrium and mechanism of Crystal Violet adsorption. Journal of Hazardous Materials, 179, 564-572 (2010).

32. Courtie, M., Epias, M., Kinetic Modeling of Methylene Blue and Crystal Violet Dyes Adsorption on Alginate-Fixed Water Hyacinth in Single and Binary Systems. American Journal of Analytical Chemistry, 4, 17-24 (2013).

33. Fumihiko, O., Noriaki, N., Naohito, K., Adsorption Capability of Cationic Dyes (Methylene Blue and Crystal Violet) onto Poly- $\gamma$-glutamic Acid. Chemical and Pharmaceutical Bulletin, 65, 268275 (2017).

34. Ahmed, I., Hisham, A., Removal of Fe (III) from aqueous solution using thiosalcylic acid as an efficient adsorbent. Egypt. Journal of Chemistry, 61, 617-627 (2018).

35. Lagergren, S., About the theory of so called adsorption of soluble substances. K. Sven. Vetenskapsakad. Handlingar Band. 24, 1- 39 (1898).

36. Ho, Y.S., McKay, G., The sorption of lead (II) ions on peat. Water Research, 33, 578 - 584 (1999).

37. Ponchami, S., Dipankar, J. B., Pankaj, D., Manash, R. D., Cationic and anionic dye removal from aqueous solution using montmorillonite clay: evaluation of adsorption parameters and mechanism. Desalination Water Treatment, 57, 8372-8388 (2016).

38. Ghebaur, A., Gârea, S.A., Iovu, H., The influence 
of inorganic host type in the drug-Layered silicate biosystems, UPB Scientific Bulletin, Series B: Chemistry and Materials Science, 73, 169-176 (2011).

39. Chen, Y-M., Tsao, T-M., Wang, M-K., Removal of crystal violet and methylene blue from aqueous solution using soil nano-clays, In: International Conference on Environment Science and Engineering. IPCBEE. 8, 252-254 (2011).

40. Aguiar, J.E., Cecilia, J.A., Tavares, P.A.S., Azevedo, D.C.S., Rodríguez, C. E., Lucena, S.M.P., Silva, J.I.J., Adsorption study of reactive dyes onto porous clay heterostructures. Applied Clay Science, 135, 35-44 (2017).

41. Davis, C.S., Matthew, A.A., Eder, C.L., Simone, F. P. P., Renato, C., Caroline, S.; Pascal S.T., Fernando, M. M., Application of Carbon Composite Adsorbents Prepared from Coffee Waste and Clay for the Removal of Reactive Dyes from Aqueous Solutions. Journal of Brazil Chemical Society, 26, 924-938 (2015).

42. Iqbal, M., Saeed, A., Biosorption of reactive dye by loofa sponge-immobilized fungal biomass of $\mathrm{P}$ Han erochaete chrysosporium. Process
Biochemical, 42, 1160-1164 (2007).

43. Zhou, Y., Zhang, M., Hu, X., Wang, X., Niu, J., Ma, T., Adsorption of Cationic Dyes on a CelluloseBased Multicarboxyl Adsorbent, Journal of Chemical Engineering Data., 58, 413-421 (2013).

44. Zafar, S.I., Bisma, M., Saeed, A., Iqbal, M., FTIR spectrophotometry, kinetics and adsorption isotherms modeling, and SEM-EDX analysis for describing mechanism of biosorption of the cationic basic dye methylene blue by a new biosorbent (sawdust of silver fir; Abies pindrow). Fresenius Environmental Bulletin, 17, 2109-2121 (2008).

45. Ahmad, R., Studies on adsorption of crystal violet dye from aqueous solution onto coniferous pinus bark powder (CPBP). Journal of Hazardous Materials, 171, 767-773 (2009).

46. Monash, P., Pugazhenthi, G., Adsorption of crystal violet dye from aqueous solution using mesoporous materials synthesized at room temperature. Adsorption 15, 390-405 (2009).

(Received 10/6/2018; accepted $17 / 10 / 2018$ )

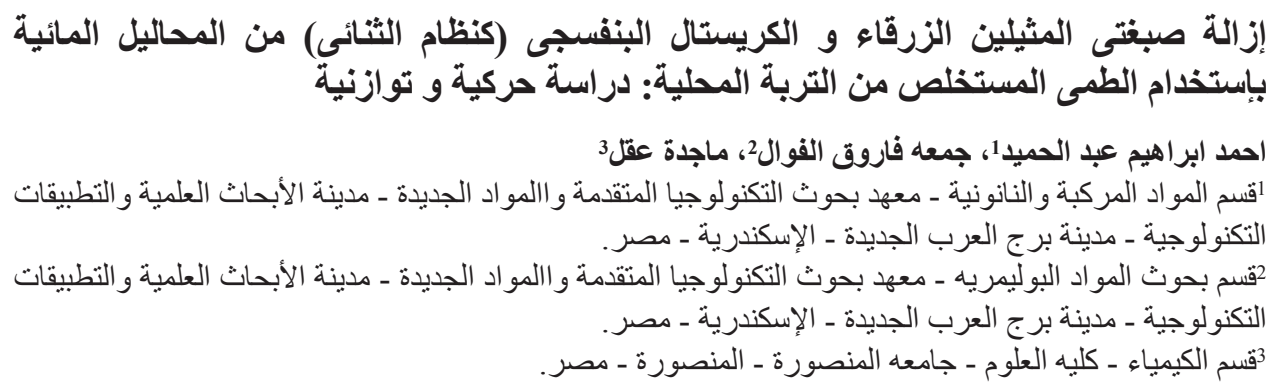

هذه الورقة تعرض إز الة الصبغة الزرقاء و البنفسجية من النظام الثنائي المائي عن طريق الامنزاز على طين التربة

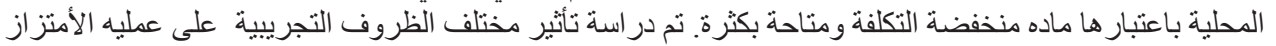

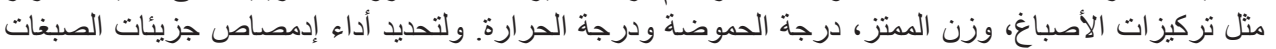

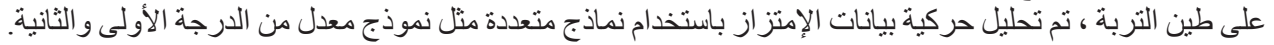

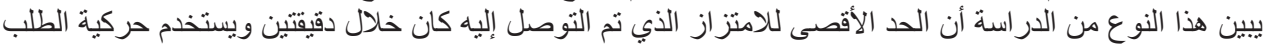

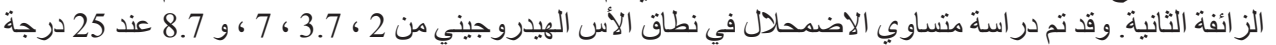

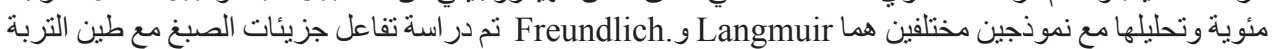

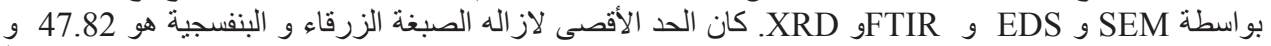
35.71 ملغم / غر ام ، على التو الي عن طريق امتصاص جزيئات الصبغات على التربة الطئة الطينية. تقدم هذة الطريقه حلاً

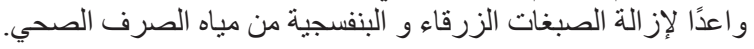

